\title{
Development of cystic glandular hyperplasia of the endometrium in Mullerian inhibitory substance type II receptor-pituitary tumor transforming gene transgenic mice
}

\author{
Shahenda M El-Naggar, Mohammad T Malik, Alvin Martin ${ }^{1}$, Joseph P Moore ${ }^{2}$, Mary Proctor ${ }^{3}$, \\ Tariq Hamid ${ }^{2}$ and Sham S Kakar ${ }^{2,4}$
}

Department of Biochemistry and Molecular Biology, ${ }^{1}$ Department of Pathology and ${ }^{2}$ Department of Medicine, ${ }^{3}$ Research Resource Center, University of Louisville, Louisville, Kentucky 40202, USA,

${ }^{4}$ James Graham Cancer Center, University of Louisville, 580 South Preston St Baxter II, 324, Louisville, Kentucky 40202, USA

(Requests for offprints should be addressed to S Kakar; Email: sskaka01@louisville.edu)

\begin{abstract}
The pituitary tumor transforming gene (PTTG)/securin is an oncogene that is involved in cell cycle regulation and sister chromatid separation. PTTG is highly expressed in various tumors including ovarian tumors, suggesting that PTTG may play a role in ovarian tumorigenesis. Overexpression of PTTG resulted in induction of cellular transformation in vitro and tumor formation in nude mice. To ascertain PTTG function in ovarian tumorigenesis, we generated a transgenic mouse model of PTTG by cloning PTTG cDNA downstream of Mullerian inhibitory substance type II receptor gene promoter $(M I S I I R)$ in order to target the ovarian surface epithelium. By screening of transgenic animals, we identified five founders (four males and one female). Using the four male founders, we developed four transgenic lines. PTTG expression was increased in ovarian surface epithelium,
\end{abstract}

ovarian granulosa cells, as well as in the pituitary gland. Transgenic females did not develop any visible ovarian tumors at 8-10 months of age; however, there was an overall increase in the corpus luteum mass in transgenic ovary, suggesting increased luteinization. These changes were associated with an increase in serum LH and testosterone levels. In addition, there was a generalized hypertrophy of the myometrium of MISIIR-PTTG transgenic uteri with cystic glandular and hyperplasia of the endometrium. Based on these results, we conclude that the overexpression of PTTG may be required to initiate precancerous conditions but is not sufficient to induce ovarian tumorigenesis and may require another partner to initiate cellular transformation.

Journal of Endocrinology (2007) 194, 179-191

\section{Introduction}

Even though ovarian cancer ranks fifth in prevalence among gynecological malignancies, it is the second deadliest (Auersperg et al. 2002). The primary reason for this fatalistic outcome is the absence of symptoms in the early stage of the disease. Unlike colon and cervical cancer, ovarian cancer has no identifiable precancerous lesions that can be used for screening (Zhang et al. 2004). In fact, screening by transvaginal ultrasonography and RIA for CA-125 (Hamilton et al. 2003, Hellstrom et al. 2003) show low specificity and sensitivity that make the two methods unreliable for detecting the initial stages of the disease. Consequently, the 5-year survival rate is $<30 \%$ (Schwartz et al. 2002). The histological classification of ovarian cancer is complex. Common ovarian tumors include epithelial, germ cell, and non-stromal sex cord. Among these ovarian cancer subtypes, epithelial ovarian cancer is the most fatal and the most common, accounting for $90 \%$ of all ovarian cancers (Vanderhyden et al. 2003). In order to understand the etiology of ovarian cancer, several animal models have been developed (Connolly et al. 2003, Garson et al. 2003, Liu et al. 2004); however, none of these was specifically targeted to epithelial cells. The major impediment for the development of mouse model of ovarian epithelial cancer is the lack of a specific promoter and oncogene that can direct gene expression to epithelial cells that lead to transformation of these cells. Recently, Connolly et al. (2003) used $5^{\prime}$ upstream region of the Mullerian inhibitory substance type II receptor (MISIIR) gene to derive tissue-specific expression of SV40 tag specifically to the epithelium of the female reproductive tract, including the ovarian surface epithelium (OSE). In their studies, 50\% of female transgenic mice developed bilateral ovarian tumors accompanied by ascites and peritoneal implants. Female MISIIR tag transgenic mice rapidly develop tumors and are nearly always infertile and die at an early age. Therefore, this ovarian tumor model has limitation in understanding the biological basis of ovarian cancer initiation and progression. 
To understand the human oncogenesis, we searched for oncogenes and cloned and characterized pituitary tumor transforming gene (PTTG) from human testis (Kakar \& Jennes 1999). Our initial studies were based on the work of Pei \& Melmed (1997), who cloned PTTG from rat pituitary tumor cell line GH4. Cloning of PTTG from various ovarian tumors revealed sequence identity with that from testis, suggesting no mutation in PTTG sequence in ovarian tumors (Puri et al. 2001). PTTG was found to be multidomain and multifunctional protein. One of its major functions reported is the inhibition of sister chromatid separation during cell cycle (Zou et al. 1999). The binding of PTTG to separase blocks sister chromatid separation until metaphase, where PTTG becomes target for ubiqitination by anaphase promoting complex (APC), thus releasing separase. The release of separase allows sister chromatid separation. Expression of PTTG is cell cycle dependent; it peaks at the G2/M phase and undergoes complete degradation at anaphase (Ramos-Morales et al. 2000).

Numerous studies have demonstrated that human PTTG displays distinct pattern of expression. In normal human tissues, PTTG expression is very restricted, with high levels in the testis and low levels in the thymus, colon, and small intestine (Pei \& Melmed 1997, Zhang et al. 1999). In contrast, PTTG is highly expressed in a variety of human primary tumors as well as tumor cell lines including carcinomas of the ovary, lung, testis, kidney, colon, thyroid, pituitary, liver, breast, prostate, melanoma, leukemia, and lymphoma (Zhang et al. 1999, Puri et al. 2001, Yu et al. 2003, Kim et al. 2005, Rehfeld et al. 2006), suggesting that PTTG may be involved in tumorigenesis of many organs. Furthermore, the expression levels of PTTG correlate with increased tumor invasiveness in human pituitary tumors with hormone overproduction (Saez et al. 1999) and degree of malignancy, pathogenesis and/or progression of colorectal, breast, and thyroid tumors (Heaney et al. 2000, Solbach et al. 2004, Kim et al. 2006). PTTG has been identified as one of the signature genes among eight genes associated with tumor metastasis that is up-regulated in human primary solid tumors (Ramaswamy et al. 2003). A relationship between the survival rate and the level of expression of PTTG in esophageal cancer has been reported (Shibata et al. 2002).

Overexpression of PTTG in NIH3T3 and HEK293 cells was found to increase cell proliferation and colony formation in soft agar and to promote tumor development in nude mice (Kakar \& Jennes 1999, Zhang et al. 1999, Hamid et al. 2005). In addition, PTTG overexpression was found to increase the secretion and the expression of basic fibroblast growth factor (bFGF; Ishikawa et al. 2001, Hamid et al. 2005), vascular endothelial growth factor (VEGF; McCabe et al. 2002, Hamid et al. 2005), interleukin-8 (IL-8; Hamid et al. 2005), MMP-2 (Malik \& Kakar 2006) and to activate the expression of c-myc (Pei 2001). To define the role of PTTG in cell proliferation and tumorigenesis, Melmed and his group showed that mice lacking PTTG (PTTG $-/-$ ) displayed aberrant cell cycle progression, premature sister chromatid separation, and chromosomal instability (Wang et al. 2001).
Furthermore, male PTTG $-/-$ mice developed testicular and splenic hypoplasia and thymic hyperplasia. In subsequent studies, these investigators showed that PTTG $-/-$ mice exhibited impaired $\beta$-cell proliferation and developed type I diabetes (Wang et al. 2003). While $80 \%$ of Rb heterozygous mice develop pituitary tumors, crossing of PTTG $(-/-)$ mice with $\mathrm{Rb}(-/+)$ decreased the prevalence of pituitary tumor development to 30\% (Chesnokova et al. 2005), suggesting a critical role of PTTG in pituitary tumorigenesis. This hypothesis is further supported by Abbud et al. (2005) who, using the $\alpha$-GSU gene promoter to target PTTG expression to the pituitary gland, showed development of pituitary adenomas, prostate hyperplasia, and an increase in serum luteinizing hormone (LH) and testosterone levels in $\alpha$-GSU-PTTG male transgenic mice. Taken together, these data strongly suggest that PTTG plays crucial role in tumorigenesis. In order to elucidate its function in ovarian epithelial cancer, we directed PTTG expression to ovarian surface epithelium using the MISIIR gene promoter. Our data shows that PTTG is capable of inducing initial cellular transformation; however, it is not sufficient for complete tumor development and may require another partner to achieve ovarian tumorigenesis.

\section{Materials and Methods}

\section{Construction of MISIIR-PTTG transgene plasmid}

PTTG cDNA was amplified using the specific primers sense 5'-TCG AAT TCG ACC TGC AAT AAT CCA GAA T-3' and antisense $5^{\prime}$-TCA GAA TTC CAC CAA ACT CTG AAG CAT T- $3^{\prime}$ from human testis as described previously (Kakar $\&$ Jennes 1999). The amplified product was then digested with EcoR1 and subcloned into pBluescript plasmid containing insulin promoter and $\beta$-globin gene (Generous gift from Dr Paul Epstein, University of Louisville). The insulin promoter was replaced by MISIIR gene promoter (kindly provided by $\mathrm{Dr}$ Denise Connolly, Fox Chase Cancer Center, Philadelphia, PA, USA). The recombinant clones were isolated and sequenced to confirm the authenticity of the sequence and orientation. Activation of the MISIIR promoter to derive the expression of PTTG gene in epithelial tumor cells was confirmed by transfecting the MISIIR-PTTG plasmid into ovarian epithelial tumor cell line A2780 as described previously (Kakar \& Jennes 1999).

\section{Generation and screening of transgenic mice}

Generation of transgenic mice was achieved by injection of MISIIR-PTTG cDNA into pronuclei injection. Briefly, transgene (MISIIR-PTTG) was excised using BamHI and XhoI restriction enzymes from the recombinant plasmid, purified, and injected into male pronuclei from hybrid $\mathrm{CD} 2 \mathrm{~F} 1(\mathrm{DBA} / 2 \mathrm{XBalb} / \mathrm{C})$ mice. Injection of the transgene was carried out by the Transgenic Core Facility, University of 
Louisville, supervised by Dr Paul Epstein. Viable oocytes were then transferred into CD2F1 pseudo pregnant females. Genotyping of the transgene was performed using tail DNA using PCR kit from Sigma using the specific primers: sense 5'-CCC TTT CTC TGC CTG TTT CC-3' (A) and antisense $5^{\prime}$-GCT TTA ACA GTC TTC TCA GT-3' (B) (Fig. 1) that specifically amplify transgene sequence. The PCR conditions were $94^{\circ} \mathrm{C}$ for $5 \mathrm{~min}, 94^{\circ} \mathrm{C}$ for $1 \mathrm{~min}$, $60{ }^{\circ} \mathrm{C}$ for $1 \mathrm{~min}$, and $72{ }^{\circ} \mathrm{C}$ for $1 \mathrm{~min}$, and repeated for five cycles followed by $94{ }^{\circ} \mathrm{C}$ for $1 \mathrm{~min}, 55^{\circ} \mathrm{C}$ for $1 \mathrm{~min}$, and $72^{\circ} \mathrm{C}$ for $1 \mathrm{~min}$ for 30 cycles.

\section{Animal housing}

Animals were housed in a conventional facility with a $12 \mathrm{~h}$ light: $12 \mathrm{~h}$ darkness cycle. All animals were treated in accordance with National Institutes of Health Guidelines for the Care and Use of Laboratory Animals and approved by Animal Use and Care Committee at the University of Louisville.

\section{Southern blot hybridization}

Southern blot hybridization was carried out to confirm the positive founders. Livers from transgenic F1 population were digested overnight at $55{ }^{\circ} \mathrm{C}$ in TNES buffer $(10 \mathrm{mM}$ Tris, $\mathrm{pH}$ $7 \cdot 5,400 \mathrm{mM} \mathrm{NaCl}, 100 \mathrm{mM}$ EDTA, $0 \cdot 6 \%$ SDS) containing proteinase $\mathrm{K}(10 \mathrm{mg} / \mathrm{ml})$. After incubation, sodium chloride was added to each sample to the final concentration of $6 \mathrm{M}$ followed by vigorous mixing for $15 \mathrm{~s}$. Samples were centrifuged at $12000-14000 \boldsymbol{g}$ for $5 \mathrm{~min}$ at room temperature. Supernatants were transferred to a new tubes and one volume of cold $95 \%$ ethanol was added to each sample. Precipitated DNA was spooled and washed with 70\% ethanol and allowed to air dry for 5-10 $\mathrm{min}$ at room temperature. The DNA pellet was resuspended in TE buffer $(10 \mathrm{mM}$ Tris, $\mathrm{pH}$ $8 \cdot 0,1 \mathrm{mM}$ EDTA). For negative control, we used mouse genomic DNA (Promega). For Southern blot hybridization, $10 \mu \mathrm{g}$ genomic DNA was digested overnight by EcoRI restriction enzyme and separated on a $0 \cdot 8 \%$ agarose gel. The gel was denatured for $45 \min (0.5 \mathrm{M} \mathrm{NaOH}, 1.5 \mathrm{M} \mathrm{NaCl})$, neutralized for $30 \mathrm{~min}(0.5 \mathrm{M}$ Tris, $1.5 \mathrm{M} \mathrm{NaCl}, \mathrm{pH} 7 \cdot 5)$, and then transferred to Nytron membrane (GE HealthCare Biosciences, Piscataway, NJ, USA) overnight in $20 \times$ SSC buffer. PTTG labeled probe was generated by restriction of PTTG cDNA from pcDNA-PTTG plasmid (Kakar \& Jennes 1999) using EcoRI and BamHI restriction enzymes, followed by labeling with $\left[\alpha_{-}{ }^{32} \mathrm{P}\right] \mathrm{dCTP}$ using random hexamer labeling kit (Promega). Membranes were u.v. cross-linked and prehybridized for $30 \mathrm{~min}$ with ExpressHyb solution (Clontech Laboratories) followed by incubation with hybridization solution containing the labeled probe for $1 \mathrm{~h}$ at $65{ }^{\circ} \mathrm{C}$. Membranes were washed for $15 \mathrm{~min}$ with $2 \times \mathrm{SSC} /$ $0 \cdot 1 \%$ SDS thrice at room temperature followed by one wash in $0 \cdot 2 \times \mathrm{SSC} / 0 \cdot 1 \% \mathrm{SDS}$ at $55{ }^{\circ} \mathrm{C}$ for $20 \mathrm{~min}$. Membranes were dried and exposed to X-ray film overnight at $-80^{\circ} \mathrm{C}$.

\section{$R N A$ isolation and analysis of gene expression by RT-PCR}

To verify the expression of the PTTG in mouse tissues, total RNA from ovary, uterus, and testis from transgenic and nonwild-type mice were isolated as described previously (Kakar \& Jennes 1999) using Trizol reagent. One microgram of RNA was used to synthesize cDNA using iScript cDNA synthesis Kit (Bio-Rad Laboratories). For PCR amplification, $2 \mu \mathrm{l}$ firststrand cDNA were used as a template in a $50 \mu \mathrm{l}$ PCR containing $5 \mu \mathrm{l} 10 \times$ PCR buffer, $4 \mu \mathrm{l}$ dNTP $(2.5 \mathrm{mM}$ each of dATG, dCTP, dGTP, and dTTP), $0 \cdot 25 \mu \mathrm{EX}$ Taq polymerase (Takara), and $200 \mathrm{nM}$ of each primer. The primers used were: sense 5'-TGG ATC CTG AGA ACT TCA GGG T-3' (C) and antisense $5^{\prime}$-GCT TTA ACA GTC TTC TCA GT-3' (B) (Fig. 1). For control, GAPDH primers used were: forward $5^{\prime}$-TGA TGA CAT CAA GAA GGT GGT- $3^{\prime}$ and GAPDH reverse $5^{\prime}$-TCC TTG GAG GCC ATG TGG GCC- $3^{\prime}$. PCR conditions were: initial denaturing at $95^{\circ} \mathrm{C}$ for $5 \mathrm{~min}, 95^{\circ} \mathrm{C}$ for $30 \mathrm{~s}, 58^{\circ} \mathrm{C}$ for $30 \mathrm{~s}, 72^{\circ} \mathrm{C}$ for $30 \mathrm{~s}$ for 30 cycles with final extension at $72{ }^{\circ} \mathrm{C}$ for $7 \mathrm{~min}$. To determine the expression of PTTG mRNA in human ovarian tumor cell line (A2780) and mouse pituitary gonadotrope cell line (LbT2), we used specific primers in PCR for human PTTG forward primer $5^{\prime}$-GACCTGCAATAATCCAGAAT- $3^{\prime}$ and reverse primer 5'-GCTTTAACAGTCTTCTCAGT-3' ${ }^{\prime}$; mouse PTTG forward primer $5^{\prime}$-GGCATCTAAGGATGGGTTGA-3' ${ }^{\prime}$ and reverse primer $5^{\prime}$-TTCGGCAACACTCTGTTGACTG-3 ${ }^{\prime}$.

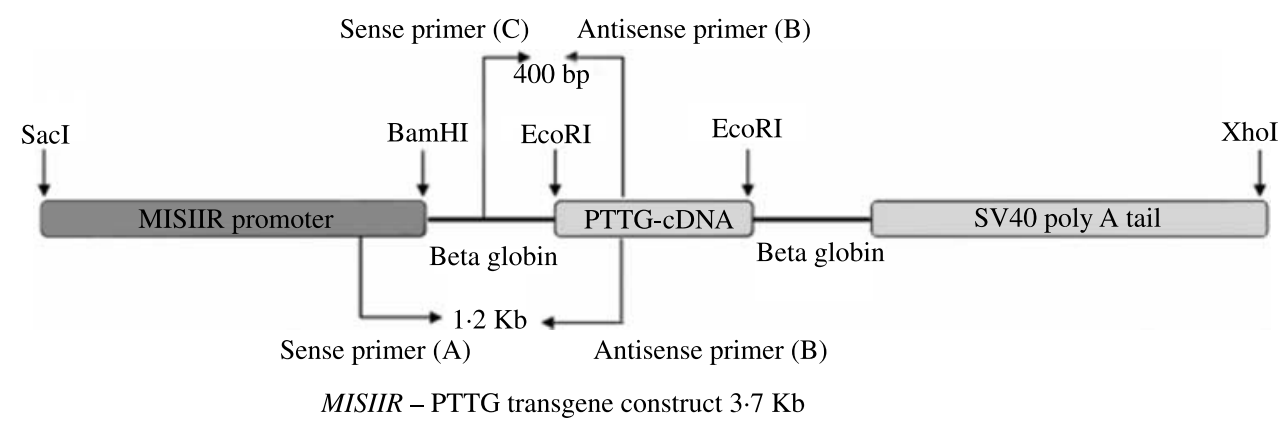

Figure 1 Generation of MISIIR-PTTG transgene. Transgenic construct used in the generation of the MISIIRPTTG transgenic mice. PTTG cDNA was cloned within $\beta$-globin gene downstream of MISIIR gene promoter. 
The PCR products were resolved on $2 \%$ agarose gels and visualized by ethidium bromide staining.

\section{Histological analyses and immunohistochemistry}

For histopathological analysis, tissues were fixed in $10 \%$ buffered formalin overnight and embedded in paraffin using standard technique. Five micrometer paraffin sections were cut and stained with H\&E by the Pathology Core Research Laboratory, University of Louisville and evaluated by human and animal pathologists (Dr Martin and Dr Proctor respectively). For immunohistochemical analysis, sections were deparaffinized in xylene and dehydrated in a graded series of alcohol. Antigen retrieval was conducted by boiling the slides in $10 \mathrm{mM}$ sodium citrate $(\mathrm{pH} 6.0)$ at $95^{\circ} \mathrm{C}$ for $30 \mathrm{~min}$ and cooled to room temperature over a period of $30 \mathrm{~min}$. Intrinsic peroxidase activity was blocked by incubation with $0.3 \% \quad \mathrm{H}_{2} \mathrm{O}_{2}$ for $10 \mathrm{~min}$. Non specific binding sites were blocked with goat normal serum $(1.5 \%)$ for 30 min followed by incubation with PTTG antiserum or PCNA monoclonal antibody clone Ab-16 (NeoMarkers) overnight in a humidified chamber at $4{ }^{\circ} \mathrm{C}$. Dilutions of PTTG antiserum and PCNA (mouse monoclonal) antibody were 1:1500 and 1:200 respectively. For PTTG protein detection, slides were washed with PBS and then treated with biotin-labeled secondary antibody (Vector laboratories Inc., Burlingame, CA, USA) according to the manufacturer's instructions. Slides were stained with 3,3'-diaminobenzidine (Sigma), washed with PBS, counterstained with hematoxylin, dehydrated, treated with xylene, and mounted. Detection of proliferating cell nuclear antigen (PCNA) was accomplished by using the mouse on mouse peroxidase kit (Vector laboratories Inc.) according to the manufacturer's instructions. Primary antibody was eliminated and goat or mouse serum was used for negative controls and analyzed in parallel. Immunohistochemical images were acquired on Nikon Eclipse E400 and ACT-1.1 imaging software (Huntley, IL, USA). Measurement of the ovary sections and quantification of immunostaining of PTTG expression in the ovarian surface epithelium were performed using Metamorph Imaging Software (version 6.2 Universal Imaging, Downingtown, PA, USA).

\section{Western blot analysis}

Western blot analysis for PTTG protein was performed as described previously (Kakar et al. 2001). A2780 and L $\beta T 2$ cell lines were cultured in complete growth media to $80-90 \%$ confluence. Cells were washed and lysed with lysis buffer (10 mM Tris-HCl, pH 7·5; 150 mM NaCl; 1\% Triton X-100; $1 \mathrm{mM}$ EDTA). Protein concentration was assayed by Bradford method (Bio-Rad Laboratories). Forty micrograms of protein from each sample were separated on a $15 \%$ SDS polyacrylamide gel and transferred to nitrocellulose membranes (GE Healthcare Biosciences). Membrane was blocked overnight with $5 \%$ nonfat milk/Tween $(20 \mathrm{mM}$ Tris-HCl, $150 \mathrm{mM} \mathrm{NaCl}, 0 \cdot 1 \%$
Tween-20, pH 7·6; tris buffered saline with Tween (TBST) and was incubated with human PTTG antiserum diluted at 1:1500, 1: 3000 , and 1: 5000 for $1 \mathrm{~h}$ at room temperature followed by washing thrice with TBST and incubation with horse radish peroxidase (HRP)-conjugated goat anti-rabbit secondary antibody diluted at 1:5000. The immune complexes formed were detected by enhanced chemiluminescence (ECL) reagents (GE HealthCare Biosciences).

\section{Measurements of serum hormone levels}

Transgenic and wild-type mice were killed and the blood was collected from the dorsal vain. Serum follicle-stimulating hormone (FSH) and LH levels were measured by Rat FSH and LH enzymeimmunoassay (EIA) kits (GE HealthCare Biosciences) according to the manufacturer's instructions. The sensitivity of the assays was $6 \cdot 25-400$ and $0 \cdot 4-100 \mathrm{ng} / \mathrm{ml}$ for FSH and LH respectively. Estradiol was assayed using Roche E170 immunoassay analyzer (electrochemiluminescent detection) at the University of Louisville Hospital laboratory. Sensitivity of the assay for estradiol (E2) was $5-4300 \mathrm{pg} / \mathrm{ml}$. Progesterone (P4) was assayed using two different systems (Roche E170 immunoassay analyzer and Cayman Chemicals, Ann Arbor, MI, USA, EIA kit). Sensitivity for P4 was $7 \cdot 8-1000 \mathrm{pg} / \mathrm{ml}$. Testosterone levels were analyzed by EIA kit (Cayman Chemicals). Sensitivity for testosterone assay was 3.4-400 pg/ml. Serum LH levels in males were measured by Rat LH RIA kit (GE Healthcare Biosciences) according to the manufacturer's protocol. All measurements were performed in duplicate except for E2 and for some samples for testosterone due to shortage of sample volume.

A

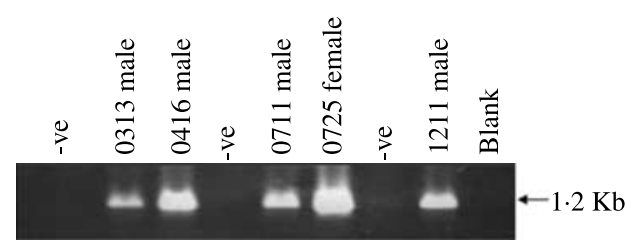

B

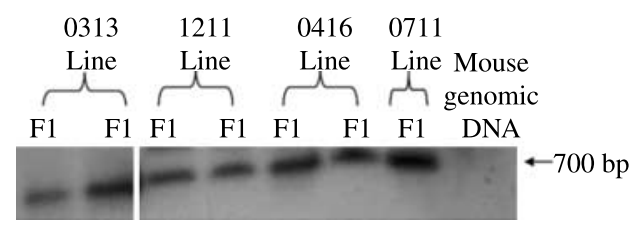

Figure 2 Identification of transgenic founders. (A) PCR analysis to identify positive founders. DNA isolated from F0 tails was used for genotyping. A $1 \cdot 2 \mathrm{~Kb}$ product was detected in four males $(0313$, 0711, 0416, and 1211) and one female (0725). (B) Southern blot analysis was used to confirm the presence of the transgene in the F1 generation. Genomic DNA isolated from liver was digested by $\mathrm{ECORI}$ at $37^{\circ} \mathrm{C}$. The digested product was resolved on a $0 \cdot 8 \%$ agarose gel and transferred to a nylon membrane. ${ }^{32} \mathrm{P}$-labeled PTTG cDNA was used as a probe. A 700 bp band was detected in F1 samples from the four founders. Mouse genomic DNA was used as a negative control. 
Statistical analysis

SigmaStat for windows was used for Student's $t$-test to determine the level of statistical significance. The level of statistical significance was set at $P<0 \cdot 05$.

\section{Results}

\section{Generation of MISIIR-PTTG transgene mice}

To define the role of PTTG in ovarian tumorigenesis and to generate a transgenic model that can be used to study biology of ovarian epithelial cancer, we selected MISIIR gene promoter to drive PTTG expression to the surface epithelium. PTTG cDNA was cloned downstream of MISIIR gene promoter (Fig. 1). To test the promoter activity to derive the expression of PTTG, we transfected ovarian epithelial carcinoma cells (A2780) with MISIIR-PTTG plasmid cDNA. Western blot analysis of the protein prepared from the cells transfected with MISIIR-PTTG plasmid showed a high level of expression of PTTG protein when compared with cells transfected with MISIIR plasmid (data not shown), indicating the expression of PTTG gene under the control of MISIIR gene promoter. The transgene construct containing the MISIIR-PTTG gene promoter and PTTG cDNA sequence was excised from the vector using SacI and XhoI restriction endonucleases, purified, and injected into male pronuclei of fertilized oocytes from hybrid CD2F1 (DBA/ 2Balb/C) mice as described in Materials and Methods.

Screening of 140 F0 by PCR analysis using tail DNA resulted in identification of five positive founders (four males and one female; Fig. 2A). The four male founders were bred with wildtype Friend Virus B-Type (FVB) females to generate four transgenic lines (0313, 0416, 0711, and 1211; Table 1). All transgenic male founders were fertile and produced a comparable size litter to wild-type, except for 1211 founder which showed a comparatively smaller size litter (Table 1). Positive male and female transgenic mice from the same line were bred to produce F2 generation (Table 2). Southern blot hybridization analysis was used to confirm the penetration of transgene to the F1 generation in all transgenic lines. A PCR product of $700 \mathrm{bp}$ was detected in all samples tested, but was absent in the negative control (Fig. 2B), suggesting the presence

Table 1 Breeding summary of transgenic founders

\begin{tabular}{|c|c|c|c|}
\hline & $\begin{array}{r}\text { Number of } \\
\text { breeding }\end{array}$ & $\begin{array}{l}\text { Total number } \\
\text { of litter }\end{array}$ & $\begin{array}{l}\text { Number of positive } \\
\text { litter in F1 }\end{array}$ \\
\hline \multicolumn{4}{|c|}{ Founder } \\
\hline 0313 & 08 (WT) & 43 & 19 \\
\hline 0711 & 10 (WT) & 82 & 17 \\
\hline 0416 & 09 (WT) & 37 & 09 \\
\hline 1211 & 10 (WT) & 29 & 10 \\
\hline 0725 & None & None & None \\
\hline
\end{tabular}

WT, Wild-type.
Table 2 Breeding summary for F2 generation

\begin{tabular}{|c|c|c|c|}
\hline & F1 generation & $\begin{array}{l}\text { F2 total } \\
\text { number } \\
\text { of litter }\end{array}$ & $\begin{array}{l}\text { Number of } \\
\text { positive } \\
\text { litter in F2 }\end{array}$ \\
\hline \multicolumn{4}{|c|}{ Founder } \\
\hline 0313 & 3 males $/ 5$ females & 42 & 34 \\
\hline 0711 & 2 males/3 females & 21 & 16 \\
\hline 1211 & 2 males/2 females & 11 & 06 \\
\hline
\end{tabular}

of transgene in the genome. Transgene female mice from F1 population appeared to be healthy and normal; however, transgenic females from F2 generation showed very aggressive behavior which resulted in the death of some mice, and in many cases, mice had to be separated and maintained in separate cages. The reasons of such aggressive behavior remain undetermined.

\section{PTTG expression in MISIIR-PTTG transgenic mice}

Transgenic and age-matched wild-type animals were killed at 8-10 months of age. Tissue distribution of transgene expression was examined using RT-PCR analysis of RNA samples isolated from the ovary, uterus, testis, stomach, and

A
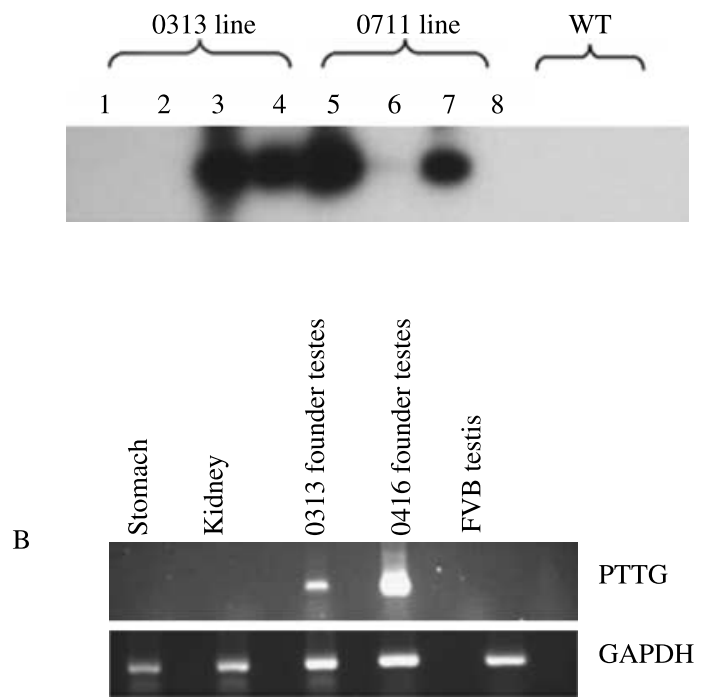

Figure 3 Transgene expression in ovaries and testes: (A) RT-PCR analysis of transgene expression in RNA isolated from ovaries of 0313 and 0711 lines and wild-type was performed as described in Material and Methods. The product was visualized by ethidium bromide staining. Samples were denatured, neutralized, and transferred overnight to nylon membranes. ${ }^{32}$ P-labeled PTTG cDNA was used as a probe, and the bands were visualized by exposing the membranes overnight to X-ray film at $-80^{\circ} \mathrm{C}$. (B) Transgene expression was detected by RT-PCR in the testes of two founders (0313 and 0416) as indicated by a band of $400 \mathrm{bp}$. RNA from FVB testes was used as a negative control. No expression was detected in the stomach or kidney tissue from transgenic animals.

Journal of Endocrinology (2007) 194, 179-191 
kidney. Four females each from the 0313 and 0711 lines were examined for transgene expression in the ovary. Using specific primers (C and B Fig. 1), a product of 400 bp was identified in $50 \%$ of transgenic females and absent in wild-type mice (Fig. 3A). On the other hand, transgene expression was not detected in the uterus of either transgenic or wild-type animals (data not shown). Furthermore, transgene expression was detected in the testes of transgenic founders and absent in male FVB testes (Fig. 3B). No expression was detected in kidney or stomach tissue from transgenic animals (Fig. 3B).

To address the affinity of the human PTTG antibody raised by us (Kakar et al. 2001) for mouse PTTG protein, we tested human PTTG antibody on two cell lines: human ovarian epithelial tumor cell line (A2780) and mouse pituitary gonadotrope tumor cell line (L $\beta$ T2). Initially, we determined the expression of PTTG mRNA in both cell lines using RT-PCR and specific primers as described in Materials and Methods. Both the cell lines showed high levels of expression of corresponding PTTG mRNA (Fig. 4A). To determine the cross-reactivity of human PTTG antibody to mouse PTTG protein, we performed western blot analysis as described previously (Kakar et al. 2001). Briefly, $40 \mu \mathrm{g}$ protein from each cell line were separated on a $15 \%$ agarose gel and subjected

A

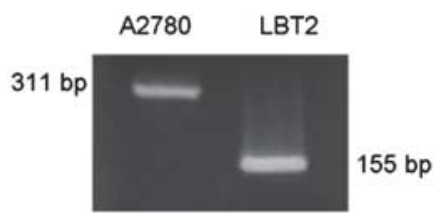

to western blot analysis. We used three dilutions of human PTTG antibody (1:1500, 1:3000, and 1:5000). As shown in Fig. $4 \mathrm{~B}$, an intense immunoreactive product was detected in A2780 cell line using all the three dilutions of human PTTG antibody. In contrast, no immunoreactive or a very weak immunoreactive product (at dilution of 1:1500) was detected in L $\beta$ T2 cell line (Fig. 4B), suggesting no or weak cross-reactivity of human PTTG antibody with mouse PTTG protein.

Immunostaining of ovarian tissue using a PTTG antiserum (Kakar et al. 2001) showed an increase in cytoplasmic staining of PTTG protein in MISIIR-PTTG transgenic ovarian epithelium when compared with wild-type (Fig. 4C, compare $\mathrm{a}$ and $\mathrm{b}$ ) and was absent in negative control (Fig. 4C and c). This was further confirmed by measuring the average intensity of PTTG expression in the ovarian epithelium. Using Metamorph software as described in Materials and Methods, the average intensity was significantly increased by $40 \%$ in transgenic females when compared with wild-type (Fig. 4D). PTTG protein was also detected in granulosa cells in transgenic animals (Fig. 5, compare a and c with b). In contrast, fewer granulosa cells were positive for PTTG staining in wild-type ovaries (which could be nonspecific binding), and no PTTG staining was detected in

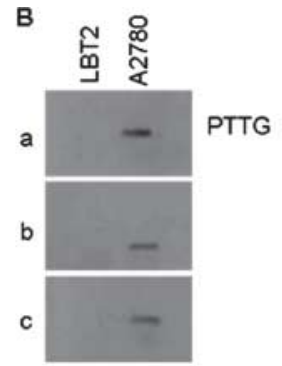

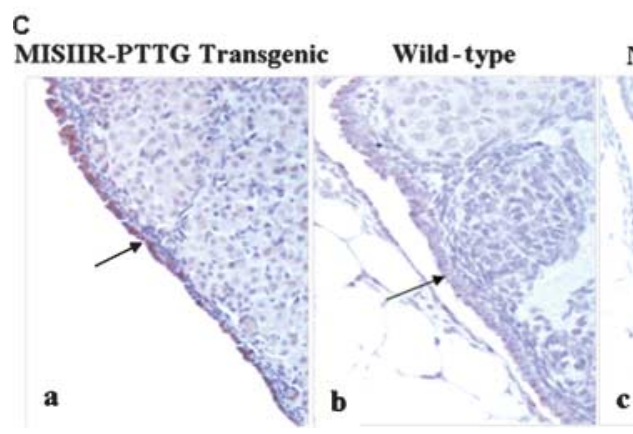
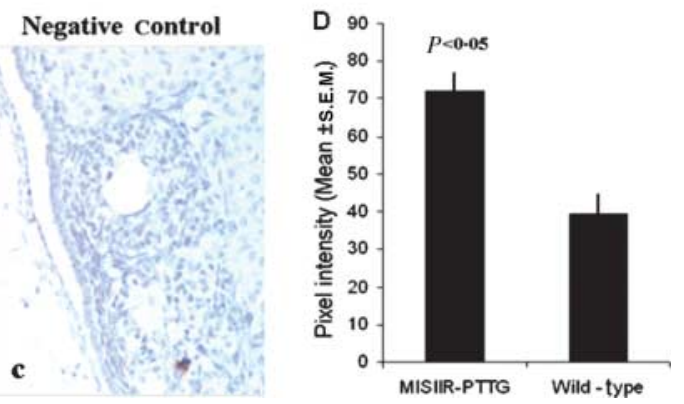

Figure 4 Expression of PTTG in human ovarian epithelial tumor cell line (A2780) and mouse gonadotrope tumor cell line (L $\beta T 2$ ). Localization of PTTG to the OSE by immunohistochemical analysis: (A) PCR analysis showed similar amount of PTTG mRNA expression from both A2780 and L $\beta$ T2 cell lines. (B) Western blot analysis of PTTG protein expression from A2780 and L $\beta T 2$ cells. Human PTTG antibody recognized PTTG protein from A2780 cell line at three different concentration $(a=1: 1500, B=1: 3000, C=1: 5000)$ but not from L $\beta$ T2 cell line. (C) PTTG protein in ovarian epithelium was detected by immunostaining for PTTG (brown) and counterstained with hematoxylin (blue). An increase in PTTG expression was observed in transgenic epithelium when compared with wild-type (compare $\mathrm{a}$ and $\mathrm{b}$ ) indicated by the black arrows. No staining was observed in sections in which primary antibody was omitted (c). (D) Average intensity of immunostaining for PTTG in the OSE from transgenic $(n=5)$ and wild-type mice $(n=3)$. Three fields were used for each section. Note that the higher the intensity, the lower the value, $P<0 \cdot 05$. All magnification from a to $c$ is $40 \times$. 


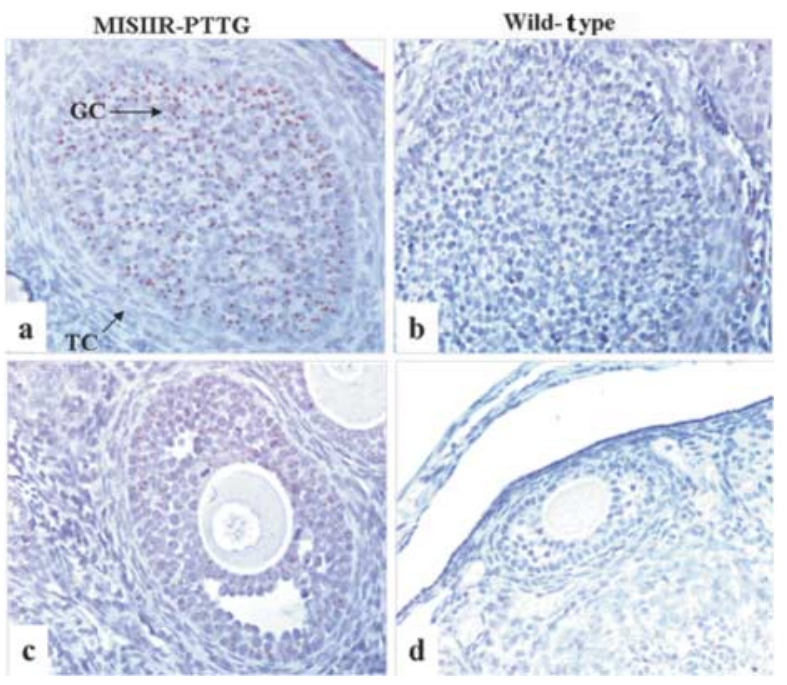

Figure 5 PTTG expression in granulosa cells. PTTG protein in granulosa (GC) cells from transgenic female mice and wild-type. Paraffin embedded tissues were stained with PTTG anti-serum as described in Material and Methods. An increase in the number of granulosa cells expressing PTTG detected in MISIIR-PTTG transgenic ovaries and absent in thecal cells (TC) (compare transgenic $a$ and $c$ with wild-type b). Arrow indicates PTTG-positive granulosa cells. No staining was detected in slides where primary antibody was omitted (d). All magnification from a to $d$ is $40 \times$.

negative control (Fig. 5d). No PTTG immunostaining was observed in the corpus luteum of either transgenic or wildtype ovaries (data not shown).

Activation of MISIIR gene promoter in pituitary has been reported (Teixeira et al. 1999). Therefore, we determined the expression of PTTG transgene in anterior pituitary. As shown in Fig. 6, an overall increase in PTTG protein expression was detected in transgenic when compared with wild-type pituitary (compare a and b). Histopathological analysis of the pituitary gland did not reveal any abnormality (data not shown). Due to unavailability of specific monoclonal antibody for each hormone for specific cell type in anterior

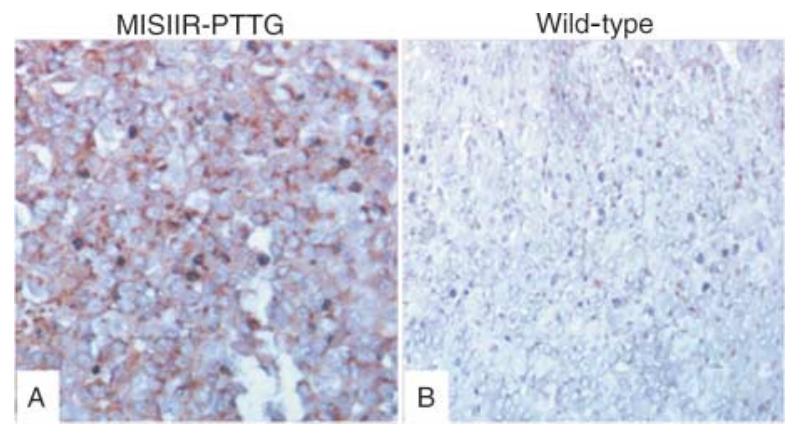

Figure 6 PTTG expression in the anterior pituitary gland. Immunohistochemical analysis of PTTG expression in the pituitary gland. An overall increase in PTTG expression was detected in the pituitary of transgenic female mice (A) when compared with wildtype (B), magnification is $\times 40$. pituitary, identification of cell type in anterior pituitary that expresses PTTG transgene protein remains unknown.

\section{Histopathology of MISIIR-PTTG transgenic mice}

To assess the consequence of PTTG expression on phenotype, female mice from $0313(n=9)$ and $0711(n=$ 10) lines were compared with eight wild-type FVB females. At least three successive sections were examined to confirm the differences. Overall, females from both F1 and F2 generations presented similar phenotypes; therefore, the data from F1 and F2 from the same line were pooled. Gross examination of transgenic ovary did not show any visible tumor. Histological examination of ovarian sections from transgenic mice revealed developing follicles. However, primary follicles were rarely noted in transgenic ovaries. Furthermore, transgenic ovaries displayed an overall increase in corpus luteum (CL) mass (Fig. 7, compare a and b) that resulted in a significant increase in ovary size (area in $\mu \mathrm{m}^{2}$ in wild-type ovaries, $3 \cdot 6 \pm 1 \cdot 98, n=5$; area for 0313 transgenic line ovaries, $6 \cdot 8 \pm 2 \cdot 1, n=5, P<0 \cdot 03$; and area for 0711 transgenic line ovaries, $6 \cdot 65 \pm 2, n=5, P<0 \cdot 03$; Fig. $7 \mathrm{c}$ ).

Histopathological analysis of the transgenic uteri revealed cystic glandular hyperplasia, which is a common phenotype associated with sustained levels of estrogen on the uterus (Tang et al. 1984). These glands were cystically dilated and were filled with fluid (Fig. 8, compare a and b with e and f). In some cases, these glands occupied the entire endometrium and displaced the stroma. There was no evidence of cycling such as scaring, hemosiderin laden macrophages, or stromal histiocytes which were prevalent in the wild-type uterus (Fig. 8, compare b and f). Furthermore, both of the luminal and glandular epithelium displayed an increase in mitotic bodies when compared with wild-type as indicated by PCNA staining (Fig. 8 compare $c$ and $d$ with g). Intense PCNA staining is indicative of higher proliferating cells in transgenic compared with wild-type (Baptist et al. 1993).

Two male founders developed abnormal growth in the testicular area at 6 months of age (Fig. 9A, a and b). Pathological examination revealed a plasmasarcoma in the preputial gland in founder 0313 (Fig. 9A and c). All transgenic males were killed at 8-10 months of age and none of them showed morphological changes in anterior pituitary or development of testicular tumor. However, there was obstruction of the urinary bladder in $60 \%$ of males examined (Fig. 9B a and b). The bladders were filled with white debris and microscopic examination indicated the presence of leukocytes $(+++)$, RBC $(+++)$, a few uric acid crystals, and bacteria.

\section{Hormone analysis}

Given that PTTG expression was targeted to two hormoneproducing tissues (ovary and pituitary), we examined the hormone profile in transgenic females by measuring serum LH, FSH, E2, P4, and testosterone levels (Table 3). At 8-10 months of age, transgenic females displayed elevated serum 

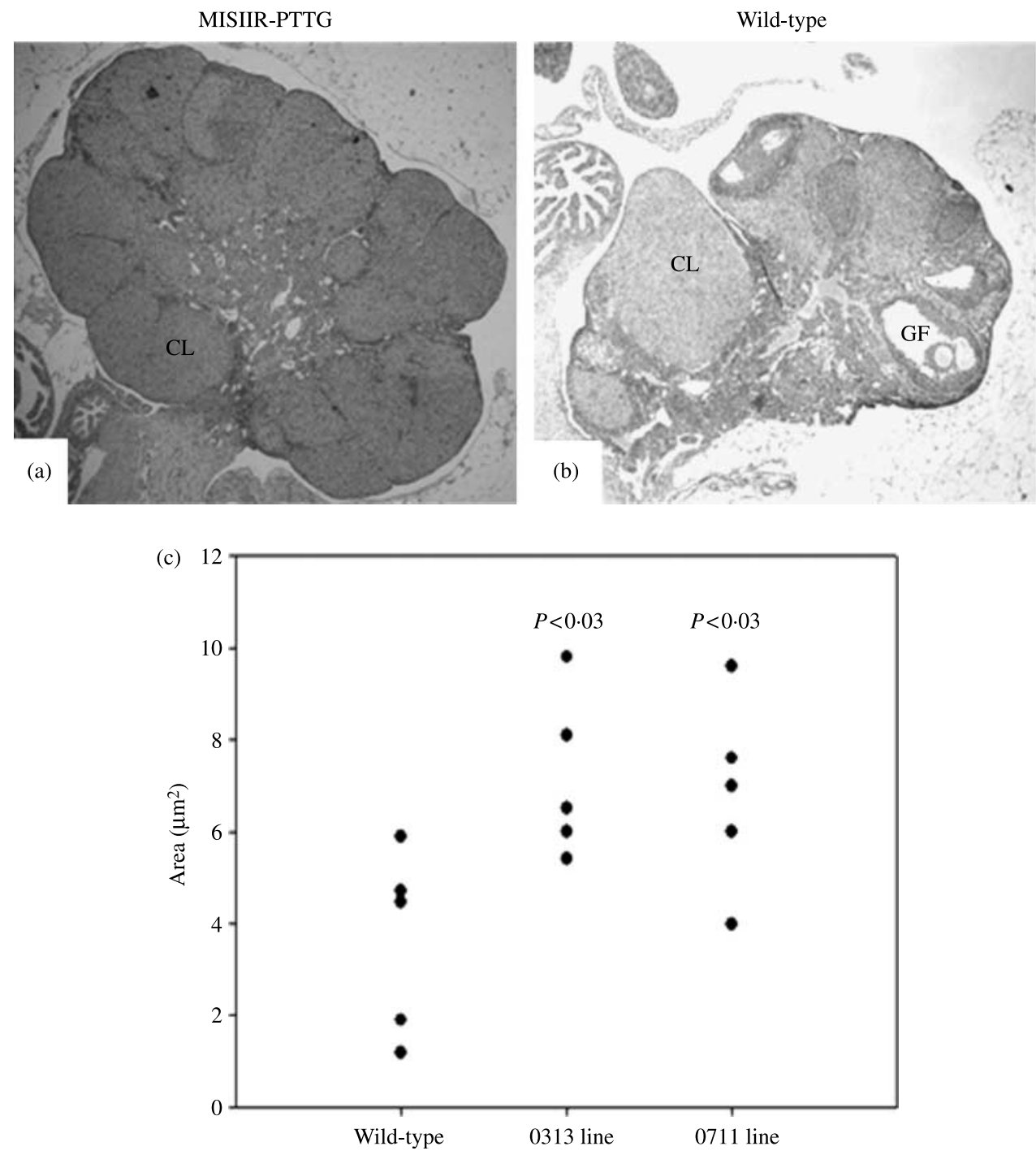

Figure 7 Histological analysis of MISIIR-PTTG transgenic ovary. Paraffin embedded ovarian sections from MISIIR-PTTG or wild-type animals were stained with H\&E. An increase in the corpus luteum mass was observed in transgenic females when compared with wild-type (compare a and b). Original magnification of both panels; $4 \times$. The size of the ovaries in $\mu \mathrm{m}^{2}$ from transgenic and wild-type animals was determined by measuring the length and the width of the histological sections at $4 \times$ magnification using Metamorph Software version 6.2. A significant increase in the transgenic ovary area was detected in both lines, $P<0.03$ (c).

LH levels when compared with wild-type (Fig. 10A). Two animals in this group showed substantially higher values (13 and $37 \mathrm{ng} / \mathrm{ml}$ respectively) and were not included in our analysis. A significance increase in testosterone levels was observed in transgenic when compared with wild-type animals (Fig. 10B). In contrast, no significant difference in serum FSH levels was observed between transgenic and wildtype animals (data not shown). Serum E2 levels were $1 \cdot 5$-fold higher in MISIIR-PTTG transgenic females when compared with wild-type (Table 3), whereas no difference in P4 levels was observed between transgenic and wild-type (Table 3). Measurement of serum LH and testosterone levels in males showed a significant increase in LH levels (twofold) and testosterone levels $(5 \cdot 3$-fold) in 0313 line when compared with wild-type (Table 3 ). Due to shortage of serum samples, we were unable to analysis for serum $\mathrm{LH}$ and testosterone levels in 0711 line.

\section{Discussion}

PTTG is highly expressed in most of the tumors including ovarian tumors. To demonstrate the oncogenic function of PTTG in the development of ovarian epithelial cancer and its 

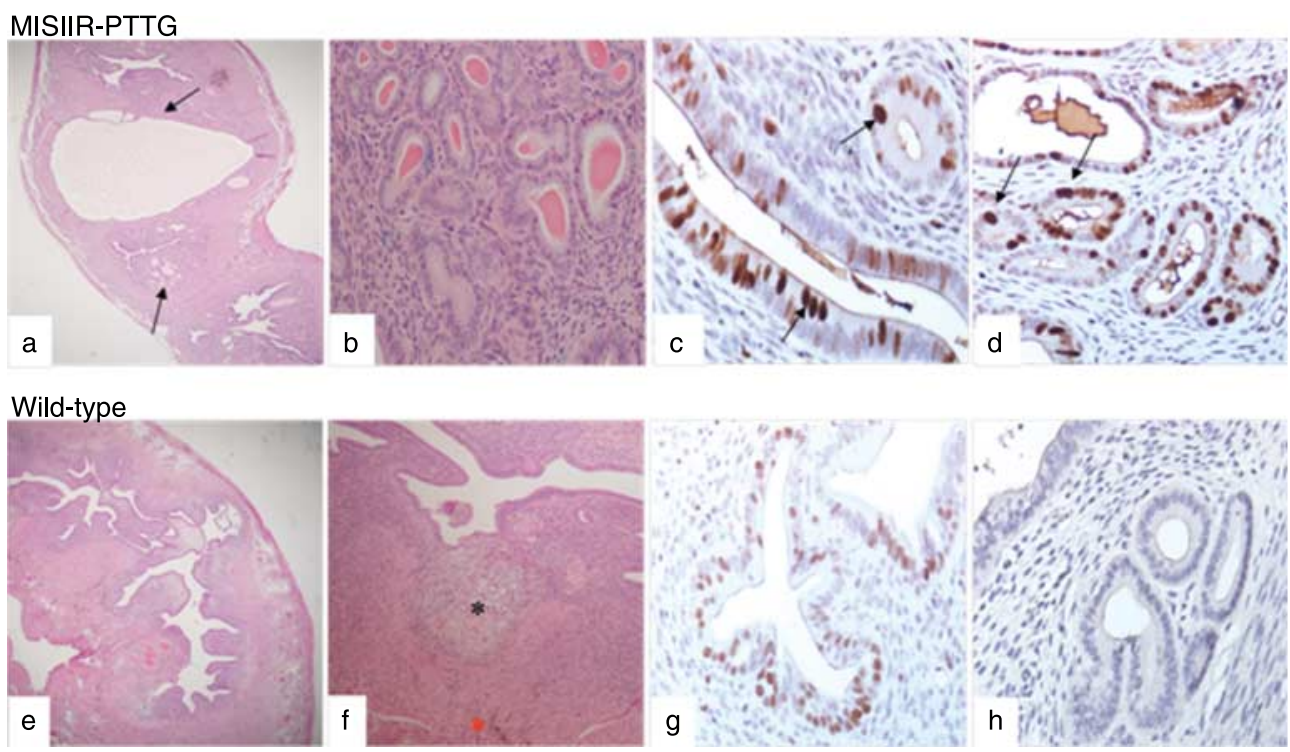

Figure 8 Histological analysis of MISIIR-PTTG transgenic uterus. Cystic glandular hyperplasia in the uterine cavity of MISIIR-PTTG female mice. The uteri from MISIIR-PTTG transgenic mice (a and b) had large cysts and multiple small fluid-filled glandular cysts (e and f). Scar formation and hemosiderin laden granules (asterisk in f) were evident in wild-type but absent in transgenic uterus. Both wild-type and transgenic uteri were PCNA positive; however, the latter showed multiple mitotic cells as indicated by dark homogeneous stained cells in both luminal and glandular epithelial cells. However PCNA staining was more intense in transgenic mice compared with wild-type indicative of higher proliferative cells. (compare transgenic $c$ and $d$ with wild-type g). Negative control sections in which primary antibody were omitted did not display any PCNA staining (h). Magnification in a and e: $10 \times$ and b, c, d, f, g, and h: $40 \times$.

A
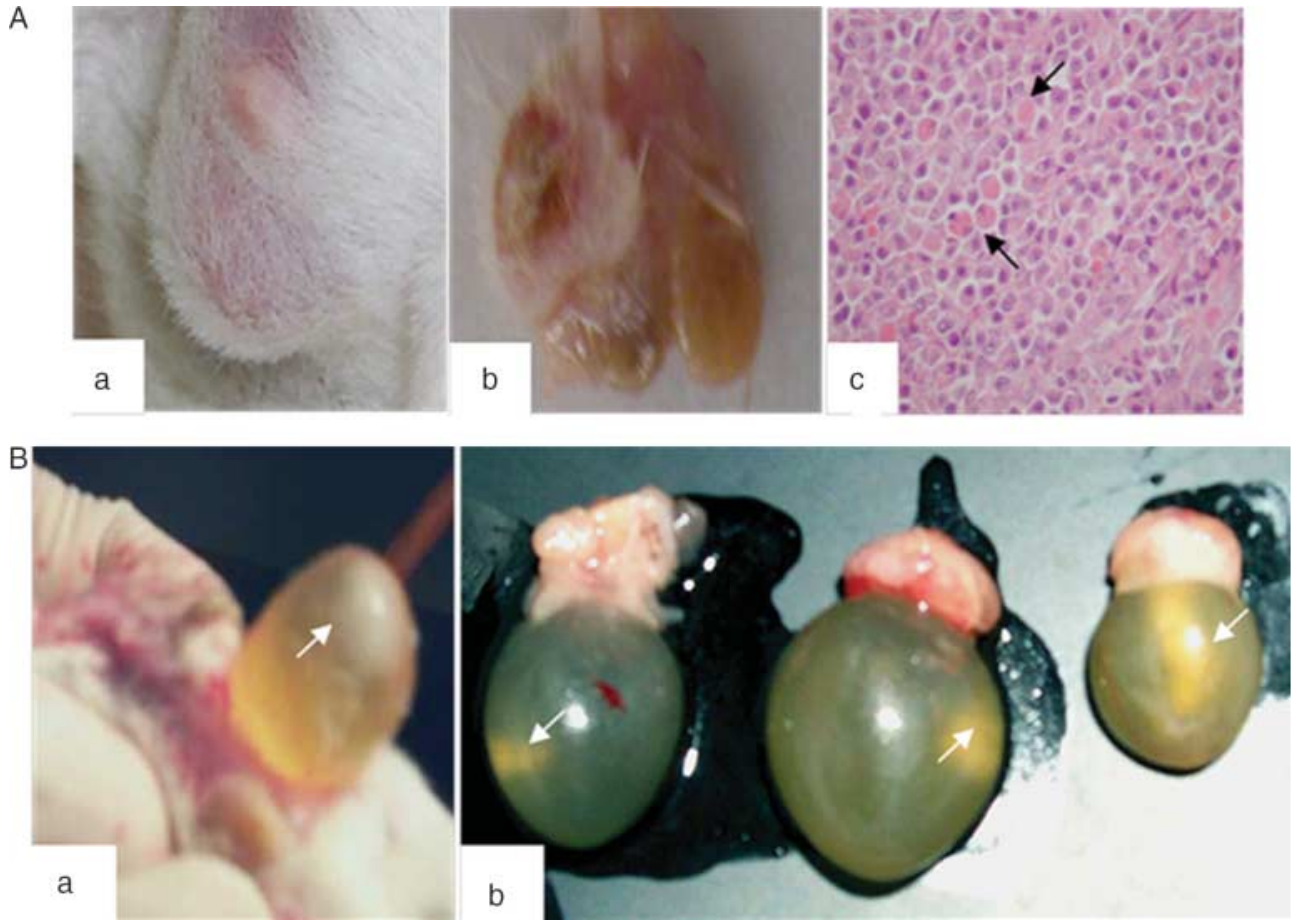

Figure 9 Phenotype changes in MISIIR-PTTG male founders (A) Growth of the preputial gland in one of the founders displaying tumor of soft tissue $(\mathrm{a}$ and $\mathrm{b})$. H\&E staining of preputial gland showing tumor of soft tissue plasmasarcoma (c). (B) Enlargement of urinary bladder in MISIIR-PTTG transgenic male which was not observed in wild-type ( $\mathrm{a}$ and b). Bladder was filled with white matter (white arrow). 

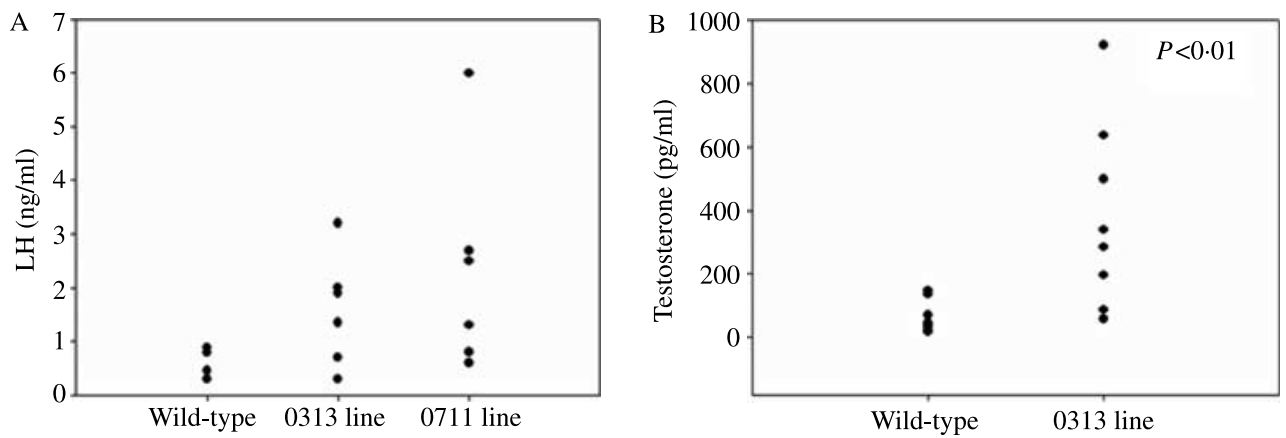

Figure 10 Serum $\mathrm{LH}$ and testosterone levels: serum concentration of $\mathrm{LH}(\mathrm{A})$ and testosterone (B) were determined in 8- to 10-month-old transgenic and wild-type female mice using EIA kit as described in Material and Methods, $P<0 \cdot 05$.

progression, we generated transgenic mice expressing PTTG under the control of MISIIR promoter. Using this approach, we were successful in targeting the PTTG transgene to the ovary and pituitary but were unable to detect transgene expression in the uterus. These results are in agreement with previous reports that MISIIR promoter is active in the ovary (Teixeira et al. 1999) and consistent with Connolly et al. (2003) who failed to detect MISIIR expression in the uterus. There was no visible tumor in any of the tissues targeted by MISIIR gene promoter in transgenic females. In spite of the high level of PTTG expression in the ovarian epithelium in transgenic animals (Fig. 4), we did not detect any evidence of tumor development. The lack of phenotypic change in the epithelium may be because ovarian surface epithelium (OSE) is much more difficult to transform and another oncogene may be required to achieve transformation. This hypothesis is based on the results from Orsulic et al. (2002), who showed induction of ovarian tumors in p53-deficient animals by adding two of the oncogenes $c-m y c, K$-ras, and Akt. Consistent with these results, Dinulescu et al. (2005) failed to develop ovarian tumors on expression of oncogenic K-ras or conditioned PTEN deletion within OSE cells. However, a combination of two mutations in the ovary led to the induction of invasive and widely metastatic endometerioid ovarian adenocarcinomas with complete penetration within 7 weeks, suggesting that the cooperation of at least two genes is required to transform ovarian epithelial cells to tumors. Another possible reason for the lack of tumor development could be due to limited level of expression of PTTG in the epithelium that is not high enough to cause transformation of OSE. Finally, we cannot exclude the possibility that PTTG expression in the OSE produced changes within the genotype, but were not sufficient to change the phenotype. Therefore, further study is required to determine changes in the gene expression within the ovarian surface epithelium in PTTG transgenic females.

Pathologically, PTTG transgenic ovaries share some properties with hCG $\beta$ and LH $\beta$-CTP transgenic mice (Risma et al. 1995, Rulli et al. 2002), such as elevated serum LH and testosterone levels and an increase in CL mass. Development of uterine cystic glandular hyperplasia in MISIIR-PTTG transgenic animals (Fig. 7) is consistent with the hCG $\beta$ transgenic uterus phenotype. Even though we observed a marginal increase in serum E2 levels in transgenic animals when compared with wild-type females, development of cystic glandular hyperplasia in the endometrium is an E2-induced effect (Tang et al. 1984), suggesting that E2 serum levels may have been elevated in transgenic females at some point prior to kill. In fact, a temporal change in E2 levels was observed in hCG $\beta$ transgenic females (Rulli et al. 2002). In spite of increased serum E2 at early age in hCG $\beta$ transgenic females, E2 returned to normal by age 2-6 months.

Overexpression of PTTG is thought to influence cell proliferation and cell survival (Wang et al. 2003, Chesnokova et al. 2005). Using the MISIIR gene promoter, we targeted PTTG to granulosa cells during the proliferative phase (Hirobe et al. 1994, Baarends et al. 1995, McGee et al.

Table 3 Hormone profile in wild-type and Mullerian inhibitory substance type II receptor (MISIIR)-PTTG transgenic animals

\begin{tabular}{l} 
Wild-type \\
\hline LH (female) \\
LH (male) \\
Testosterone (female) \\
Testosterone (male) \\
Estradiol (female) \\
Progesterone (female)
\end{tabular}

\begin{tabular}{l} 
Mean \pm s.E.M. \\
\hline $0 \cdot 6 \mathrm{ng} / \mathrm{ml} \pm 0 \cdot 13 ; n=4$ \\
$1 \cdot 09 \mathrm{ng} / \mathrm{ml} \pm 0 \cdot 06 ; n=4$ \\
$65 \mathrm{pg} / \mathrm{ml} \pm 17 \cdot 7 ; n=8$ \\
$335 \cdot 6 \mathrm{pg} / \mathrm{ml} \pm 18 \cdot 5 ; n=5$ \\
$7 \cdot 4 \mathrm{pg} / \mathrm{ml} \pm 1 \cdot 2 ; n=3$ \\
$7 \mathrm{ng} / \mathrm{ml} \pm 1 \cdot 3 ; n=8$
\end{tabular}

\section{MISIIR-PTTG}

0313 line

0313 line

0313 line

0313 line

0313 line

0313 line

\begin{tabular}{l} 
Mean \pm S.E.M. \\
\hline $1 \cdot 5 \mathrm{ng} / \mathrm{ml} \pm 0 \cdot 4 ; n=6$ \\
$2 \cdot 1 \mathrm{ng} / \mathrm{ml} \pm 0 \cdot 01 ; n=9$ \\
$377 \cdot 7 \mathrm{pg} / \mathrm{ml} \pm 103 \cdot 8 ; n=8$ \\
$1773 \mathrm{pg} / \mathrm{ml} \pm 19 \cdot 8 ; n=9$ \\
$11 \mathrm{pg} / \mathrm{ml} \pm 0 \cdot 9 ; n=6$ \\
$7 \cdot 1 \mathrm{ng} / \mathrm{ml} \pm 1 \cdot 4 ; n=6$
\end{tabular}


2001). During the proliferative phase, a dominant follicle is selected and E2 is produced. Increased levels of E2 suppress the development of other follicles by inhibiting FSH secretion from the pituitary gland, thus allowing fewer follicles to continue to ovulation. However, the continuous rise in circulating E2 from developing follicles will stimulate the pituitary gland to produce $\mathrm{LH}$, causing the $\mathrm{LH}$ surge that induces ovulation. Since MISIIR promoter targets PTTG expression to granulosa cells during proliferative phase, we hypothesize that PTTG may promote follicle survival, enhancing folliculogenesis and decreasing follicular apoptosis. This may result in an increase in the overall E2 levels. This can explain the development of cystic glandular hyperplasia of the endometrium observed in PTTG transgenic female mice. Whether that translates in increased ovulation in transgenic animals remains unclear. Unlike LH $\beta-C T P$ and hCG $\beta$ models, PTTG transgenic females were fertile at least up to 3 months of age and produced average size litter. However, histological analysis of the uterus at 8-10 months did not show any evidence of cycling, suggesting that the reproductive cycle was altered in these animals at later stage.

Immunohistochemical analysis of the anterior pituitary from the transgenic females demonstrated an overall increase in PTTG expression in the anterior pituitary of transgenic mice (Fig. 6). Teixeira et al. (1999) reported the presence of MISIIR gene expression in the anterior pituitary. This suggests that PTTG expression in the pituitary could be a direct effect of MISIIR promoter activity. If indeed E2 was elevated, then we may anticipate that E2 had influenced PTTG levels in the pituitary (Heaney et al. 1999, 2002). However, our human PTTG antibody did not cross-react with murine PTTG protein; therefore, increase in PTTG expression observed in anterior pituitary is result of activation of MISIIR gene promoter in anterior pituitary. Possibility of increase in endogenous PTTG expression as a result of increase in E2 levels is not ruled out. Recently, Abbud et al. (2005) reported an increase in expression of PTTG in anterior pituitary cells in male transgenic animals using $\alpha$-GSU promoter, leading to increase in serum LH levels. Based on these results, an increase in serum LH levels in female transgenic animals observed in our studies could be result of increased PTTG expression in the anterior pituitary. Consistent with hCG $\beta$ and LH $\beta$-CTP mice models (Risma et al. 1995, Rulli et al. 2002), MISIIR-PTTG transgenic females showed a significant increase in serum testosterone levels which may be contributing to the aggressive behavior observed in PTTG transgenic females. Unlike hCG $\beta$ and LH $\beta$-CTP mice model, PTTG transgenic females did not show elevated P4 levels despite the massive luteinization. This difference may be explained by the fact that serum $\mathrm{LH}$ in PTTG transgenic animals was increased by approximately threefold (Table 3), while both hCG $\beta$ and LH $\beta$-CTP models LH levels were elevated by 5 - and 40 -fold respectively. On the other hand, serum testosterone levels in each model were increased by sixfold. One may conclude that there is an enhanced synthesis of testosterone in PTTG transgenic females even with the moderate elevation in LH levels. Since P4 is an early precursor in steroid biosynthesis, we hypothesize that enhanced conversion of $\mathrm{P} 4$ to testosterone is masking any potential changes in $\mathrm{P} 4$ levels. Although testosterone primarily produced in thecal cells by the action of type 5,17- $\beta$-HSD (Luu-The et al. 2001), the expression of this enzyme in the corpus luteum (Pelletier et al. 1999) suggests that it may influence testosterone production in the luteal phase. Despite the sex difference, $\boldsymbol{\alpha}$-GSU transgenic males also showed elevated serum LH and testosterone, suggesting that PTTG expression influences the synthesis of both hormones.

MISIIR-PTTG transgenic male mice presented with enlarged urinary bladder (Fog-10). The cause of the enlargement of bladder in MISIIR-PTTG males remains unknown. However, bladder obstruction is associated with prostate hyperplasia as observed in $\alpha$-GSU-PTTG and mitogen activated protein kinase $\mathrm{T}$ (MAPKT) models (Majumder et al. 2003). Therefore, enlargement of bladder in male transgenic animals might be due to elevated levels of serum LH and testosterone. MISIIR expression has been reported in prostate gland by Teixeira et al. (1999), suggesting that direct expression of PTTG in the prostate may also contribute to this phenotype.

In summary, using MISIIR gene promoter, we targeted PTTG expression to three different tissues, ovarian surface epithelium, granulosa cells, and pituitary. None of these tissues developed any visible tumor. PTTG transgenic females presented with increased ovary size, hyperplasia of the endometrium, and increased serum $\mathrm{LH}$ and testosterone levels. These data suggest that PTTG is capable of inducing initial transformation but is not sufficient for tumorigenesis, and may require a hormonal trigger or cooperation of other gene(s), such as inactivation of $\mathrm{p} 53$, to initiate tumorigenesis and to promote tumor growth.

\section{Acknowledgements}

Authors are thankful to Dr Barbara Clark and Dr Stephen Winters for editing the manuscript. Authors are also thankful to Dr Paul Epstein for his help in injection of transgene to generate transgenic animals. This work was supported by a grants from NIH/NCI CA82511 and CA124630 (S S K), Competitive Enhancement Grant (S S K) from University of Louisville, Kentucky Lung Cancer Program Research Grant (S S K), and The Endocrine Society Bridge Fund Program (S S K). The authors declare that there is no conflict of interest that would prejudice the impartiality of this scientific work.

\section{References}

Abbud RA, Takumi I, Barker EM, Ren SG, Chen DY, Wawrowsky K \& Melmed S 2005 Early multipotential pituitary focal hyperplasia in the alpha-subunit of glycoprotein hormone-driven pituitary tumor-transforming gene transgenic mice. Molecular Endocrinology 19 1383-1391. 
Auersperg N, Ota T \& Mitchell GW 2002 Early events in ovarian epithelial carcinogenesis: progress and problems in experimental approaches. International Journal of Gynecological Cancer 12 691-703.

Baarends WM, Uilenbroek JT, Kramer P, Hoogerbrugge JW, van Leeuwen EC, Themmen AP \& Grootegoed JA 1995 Anti-mullerian hormone and anti-mullerian hormone type II receptor messenger ribonucleic acid expression in rat ovaries during postnatal development, the estrous cycle, and gonadotropin-induced follicle growth. Endocrinology 136 4951-4962.

Baptist M, Dumont JE \& Roger PP 1993 Demonstration of cell cycle kinetics in thyroid primary culture by immunostaining of proliferating cell nuclear antigen: difference in cAMP- dependent and independent mitogenic stimulations. Journal of Science Cell 105, 69-80.

Chesnokova V, Kovacs K, Castro AV, Zonis S \& Melmed S 2005 Pituitary hypoplasia in $\mathrm{Pttg}-/-$ mice is protective for $\mathrm{Rb}+/-$ pituitary tumorigenesis. Molecular Endocrinology 19 2371-2379.

Connolly DC, Bao R, Nikitin AY, Stephens KC, Poole TW, Hua X, Harris SS, Vanderhyden BC \& Hamilton TC 2003 Female mice chimeric for expression of the simian virus $40 \mathrm{TAg}$ under control of the MISIIR promoter develop epithelial ovarian cancer. Cancer Research 63 1389-1397.

Dinulescu DM, Ince TA, Quade BJ, Shafer SA, Crowley D \& Jacks T 2005 Role of K-ras and Pten in the development of mouse models of endometriosis and endometrioid ovarian cancer. Nature Medicine 11 63-70.

Garson K, Macdonald E, Dube M, Bao R, Hamilton TC \& Vanderhyden BC 2003 Generation of tumors in transgenic mice expressing the SV40 T antigen under the control of ovarian-specific promoter 1. Journal of the Society for Gynecologic Investigation 10 244-250.

Hamid T, Malik M \& Kakar S 2005 Ectopic expression of PTTG1/securin promotes tumorigenesis in human embryonic kidney cells. Molecular Cancer 43.

Hamilton TC, Connolly DC, Nikitin AY, Garson K \& Vanderhyden BC 2003 Translational research in ovarian cancer: a must. International Journal of Gynecological Cancer 13 220-230.

Heaney AP, Horwitz GA, Wang Z, Singson R \& Melmed S 1999 Early involvement of estrogen-induced pituitary tumor transforming gene and fibroblast growth factor expression in prolactinoma pathogenesis. Nature Medicine 5 1317-1321.

Heaney AP, Singson R, McCabe CJ, Nelson V, Nakashima M \& Melmed S 2000 Expression of pituitary-tumour transforming gene in colorectal tumours. Lancet 355 716-719.

Heaney AP, Fernando M \& Melmed S 2002 Functional role of estrogen in pituitary tumor pathogenesis. Journal of Clinical Investigation 109 277-283.

Hellstrom I, Raycraft J, Hayden-Ledbetter M, Ledbetter JA, Schummer M, McIntosh M, Drescher C, Urban N \& Hellstrom KE 2003 The HE4 (WFDC2) protein is a biomarker for ovarian carcinoma. Cancer Research $\mathbf{6 3}$ 3695-3700.

Hirobe S, He WW, Gustafson ML, MacLaughlin DT \& Donahoe PK 1994 Mullerian inhibiting substance gene expression in the cycling rat ovary correlates with recruited or graafian follicle selection. Biology of Reproduction 50 1238-1243.

Ishikawa H, Heaney AP, Yu R, Horwitz GA \& Melmed S 2001 Human pituitary tumor-transforming gene induces angiogenesis. Journal of Clinical Endocrinology and Metabolism 86 867-874.

Kakar SS \& Jennes L 1999 Molecular cloning and characterization of the tumor transforming gene (TUTR1): a novel gene in human tumorigenesis. Cytogenetics and Cell Genetics 84 211-216.

Kakar SS, Chen L, Puri R, Flynn SE \& Jennes L 2001 Characterization of a polyclonal antibody to human pituitary tumor transforming gene 1 (PTTG1) protein. Journal of Histochemistry and Cytochemistry 49 1537-1546.

Kim D, Pemberton H, Stratford AL, Buelaert K, Watkinson JC, Lopes V, Franklyn JA \& McCabe CJ 2005 Pituitary tumour transforming gene $(P T T G)$ induces genetic instability in thyroid cells. Oncogene 24 4861-4866.

Kim DS, Franklyn JA, Stratford AL, Boelaert K, Watkinson JC, Eggo MC \& McCabe CJ 2006 Pituitary tumor-transforming gene regulates multiple downstream angiogenic genes in thyroid cancer. Journal of Clinical Endocrinology and Metabolism 91 1119-1128.
Liu J, Yang G, Thompson-Lanza JA, Glassman A, Hayes K, Patterson A, Marquez RT, Auersperg N, Yu Y, Hahn WC et al. 2004 A genetically defined model for human ovarian cancer. Cancer Research 64 1655-1663.

Luu-The V, Dufort I, Pelletier G \& Labrie F 2001 Type 5 17betahydroxysteroid dehydrogenase: its role in the formation of androgens in women. Molecular and Cellular Endocrinology 171 77-82.

Majumder PK, Yeh JJ, George DJ, Febbo PG, Kum J, Xue Q, Bikoff R, Ma H, Kantoff PW, Golub TR et al. 2003 Prostate intraepithelial neoplasia induced by prostate restricted Akt activation. PNAS 100, 7841-7846.

Malik MT \& Kakar SS 2006 Regulation of angiogenesis and invasion by human pituitary tumor transforming gene (PTTG) through increased expression and secretion of matrix metalloproteinase-2 (MMP-2). Molecular Cancer 561

McCabe CJ, Boelaert K, Tannahill LA, Heaney AP, Stratford AL, Khaira JS, Hussain S, Sheppard MC, Franklyn JA \& Gittoes NJL 2002 Vascular endothelial growth factor, its receptor KDR/Flk-1, and pituitary tumor transforming gene in pituitary tumors. Journal of Clinical Endocrinology and Metabolism 87 4238-4244.

McGee EA, Smith R, Spears N, Nachtigal MW, Ingraham H \& Hsueh AJ 2001 Mullerian inhibitory substance induces growth of rat preantral ovarian follicles. Biology of Reproduction 64 293-298.

Orsulic S, Li Y, Soslow RA, Vitale-Cross LA, Gutkind JS \& Varmus HE 2002 Induction of ovarian cancer by defined multiple genetic changes in a mouse model system. Cancer Cell 1 53-62.

Pei L 2001 Identification of c-myc as a down-stream target for pituitary tumor-transforming gene. Journal of Biological Chemistry 276 8484-8491.

Pei L \& Melmed S 1997 Isolation and characterization of a pituitary tumortransforming gene (PTTG). Molecular Endocrinology 11 433-441.

Pelletier G, Luu-The V, Tetu B \& Labrie F 1999 Immunocytochemical localization of type 5 17beta-hydroxysteroid dehydrogenase in human reproductive tissues. Journal of Histochemistry and Cytochemistry 47 731-738.

Puri R, Tousson A, Chen L \& Kakar SS 2001 Molecular cloning of pituitary tumor transforming gene 1 from ovarian tumors and its expression in tumors. Cancer Letters 163 131-139.

Ramaswamy S, Ross KN, Lander ES \& Golub TR 2003 A molecular signature of metastasis in primary solid tumors. Nature Genetics 33 49-54.

Ramos-Morales F, Dominguez A, Romero F, Luna R, Multon MC, PintorToro JA \& Tortolero M 2000 Cell cycle regulated expression and phosphorylation of hpttg proto-oncogene product. Oncogene 19 403-409.

Rehfeld N, Geddert H, Atamna A, Rohrbeck A, Garcia G, Kliszewski S, Neukirchen J, Bruns I, Steidl U, Fenk R et al. 2006 The influence of the pituitary tumor transforming gene-1 (PTTG-1) on survival of patients with small cell lung cancer and non-small cell lung cancer. Journal of Carcinogenesis 54.

Risma KA, Clay CM, Nett TM, Wagner T, Yun J \& Nilson JH 1995 Targeted overexpression of luteinizing hormone in transgenic mice leads to infertility, polycystic ovaries, and ovarian tumors. PNAS 92 1322-1326.

Rulli SB, Kuorelahti A, Karaer O, Pelliniemi LJ, Poutanen M \& Huhtaniemi I 2002 Reproductive disturbances, pituitary lactotrope adenomas, and mammary gland tumors in transgenic female mice producing high levels of human chorionic gonadotropin. Endocrinology 143 4084-4095.

Saez C, Japon MA, Ramos-Morales F, Romero F, Segura DI, Tortolero M \& Pintor-Toro JA $1999 \mathrm{hpttg}$ is over-expressed in pituitary adenomas and other primary epithelial neoplasias. Oncogene 18 5473-5476.

Schwartz DR, Kardia SLR, Shedden KA, Kuick R, Michailidis G, Taylor JMG, Misek DE, Wu R, Zhai Y, Darrah DM et al. 2002 Gene expression in ovarian cancer reflects both morphology and biological behavior, distinguishing clear cell from other poor-prognosis ovarian carcinomas. Cancer Research 62 4722-4729.

Shibata Y, Haruki N, Kuwabara Y, Nishiwaki T, Kato J, Shinoda N, Sato A, Kimura M, Koyama H, Toyama T et al. 2002 Expression of pituitary tumor transforming gene $(P T T G)$ in esophageal cancer. Japanese Journal of Clinical Oncology 32 233-237.

Solbach C, Roller M, Fellbaum C, Nicoletti M \& Kaufmann M 2004 PTTG mRNA expression in primary breast cancer: a prognostic marker for lymph node invasion and tumor recurrence. Breast 13 80-81. 
Tang FY, Bonfiglio TA \& Tang LK 1984 Effect of estrogen and progesterone on the development of endometrial hyperplasia in the Fischer rat. Biology of Reproduction 31 399-413.

Teixeira J, Kehas DJ, Antun R \& Donahoe PK 1999 Transcriptional regulation of the rat Mullerian inhibiting substance type II receptor in rodent Leydig cells. PNAS 96 13831-13838.

Vanderhyden B, Shaw T \& Ethier J-F 2003 Animal models of ovarian cancer. Reproductive Biology and Endocrinology 167.

Wang Z, Yu R \& Melmed S 2001 Mice lacking pituitary tumor transforming gene show testicular and splenic hypoplasia, thymic hyperplasia, thrombocytopenia, aberrant cell cycle progression, and premature centromere division. Molecular Endocrinology 15 1870-1879.

Wang Z, Moro E, Kovacs K, Yu R \& Melmed S 2003 Pituitary tumor transforming gene-null male mice exhibit impaired pancreatic beta cell proliferation and diabetes. PNAS 100 3428-3432.

Yu R, Lu W, Chen J, McCabe CJ \& Melmed S 2003 Overexpressed pituitary tumor-transforming gene causes aneuploidy in live human cells. Endocrinology 144 4991-4998.
Zhang X, Horwitz GA, Prezant TR, Valentini A, Nakashima M, Bronstein MD \& Melmed S 1999 Structure, expression, and function of human pituitary tumor-transforming gene (PTTG). Molecular Endocrinology 13 156-166.

Zhang Z, Bast RC Jr, Yu Y, Li J, Sokoll LJ, Rai AJ, Rosenzweig JM, Cameron B, Wang YY, Meng X-Y et al. 2004 Three biomarkers identified from serum proteomic analysis for the detection of early stage ovarian cancer. Cancer Research 64 5882-5890.

Zou H, McGarry TJ, Bernal T \& Kirschner MW 1999 Identification of a vertebrate sister-chromatid separation inhibitor involved in transformation and tumorigenesis. Science 285 418-422.

Received in final form 24 March 2007

Accepted 28 March 2007

Made available online as an Accepted Preprint 11 April 2007 